\title{
Petrological and Geochemical Studies on the Si-Undersaturated Rocks of the Mount Cameroon: Genesis of the Camptonite and Nephelinite at the Cameroon Hot Line
}

\author{
Ntoumbé Mama1 ${ }^{*}$, Amaya Adama², Diguim Kepnamou Amadou1, \\ Mbowou Gambie Isaac Bertrand', Naimou Seguem³, Ngounouno Ismaïla1 \\ ${ }^{1}$ Department of Mines Geology, School of Geology and Mining Engineering, University of Ngaoundere, Meiganga, Cameroon \\ ${ }^{2}$ Department of Geomatic and Geology Mapping, School of Geology and Mining Engineering, University of Ngaoundere, \\ Meiganga, Cameroon \\ ${ }^{3}$ Department of Geology, Faculty of Sciences and Techniques, University Adam Barka of Abeche, Abeche, Chad \\ Email: *ntoumbe2@hotmail.com
}

How to cite this paper: Mama, N., Adama, A., Amadou, D.K., Bertrand, M.G.I., Seguem, N. and Ismaila, N. (2021) Petrological and Geochemical Studies on the Si-Undersaturated Rocks of the Mount Cameroon: Genesis of the Camptonite and Nephelinite at the Cameroon Hot Line. Open Journal of Geology, 11, 239-252. https://doi.org/10.4236/ojg.2021.116014

Received: April 13, 2021

Accepted: June 22, 2021

Published: June 25, 2021

Copyright $\odot 2021$ by author(s) and Scientific Research Publishing Inc. This work is licensed under the Creative Commons Attribution International License (CC BY 4.0).

http://creativecommons.org/licenses/by/4.0/

\section{(c) (i) Open Access}

\begin{abstract}
The Cameroon hot line is dominated by magmatic rocks. The variations of magma and chemistry are generally due to the difference of physical conditions and chemistry in the magma source region during the ascent of magma. The Mt Etinde and the Mt Cameroon, both edifices belong to the Cameroon Hot line, have a particularity some rare rocks such as camptonite and nephelinite. The relationship between the silica undersaturated rocks in the both edifices is characterized by the lateral variation appear through the petrography of the different rocks. The concerned geochemical data allow to compare the Mount Etinde nephelinite and Mount Cameroon camptonite where the differentiation process reflects geochemical affinities from a basaltic magma source on the Cameroon hot line. The compatible elements between the Mount Etinde nephelinite and the Mount Cameroon camptonite and basalt correlate with the difference in modal compositions of mineral phases. The lateral variation of major and trace element contents in the Mount Cameroon camptonite and Mount Etinde nephelinite seem to be related to the difference in the fractional crystallization processes of mineral phases, the difference in the partial melting processes and the metasomatism source rich in volatile. The silica-undersaturated character of the camptonite and nephelinite could be attributed to assimilation of carbonate rocks within depth-level magma chambers. Trace element AFC modelling revealed that the parental magmas of both edifice volcanic rocks were mostly affected by fractional crystallisation coupled with metasomatism process in Ca rich source.
\end{abstract}




\section{Keywords}

Nephelinite, Camptonite, Link, Source, Cameroon Hot Line

\section{Introduction}

Mount Cameroon $4^{\circ} 1^{\prime} \mathrm{N}-9^{\circ} 6^{\prime} \mathrm{E}$ and $4^{\circ} 19^{\prime} \mathrm{N}-9^{\circ} 15^{\prime} \mathrm{E}$ is located in south-western Cameroon Region and rises from the Atlantic coast to a height of $4095 \mathrm{~m}$. Mount Etinde is a small densely forested and highly dissected volcano located on the SW flank of Mount Cameroon. It situated on the south-westely side of the Mount Cameroon volcano (one of Africa's most active volcanoes), between latitude $4^{\circ} 1^{\prime}$ and $4^{\circ} 6^{\prime}$ and longitude $9^{\circ} 5^{\prime} \mathrm{E}$ and $9^{\circ} 8^{\prime} \mathrm{E}$, along the Atlantic coast of West Africa. It raises to a height of $1713 \mathrm{~m}$ with the lavas compositions entirely of the silica undersaturated rocks (i.e. nephelinites). The Mount Cameroon is extensively covered by cinder cones, explosive craters, where lava flows and scoraceous lapilli cover a total area of $\sim 1116 \mathrm{~km}^{2}$ included the Mount Etinde edifice [1]. The Mount Cameroon and Etinde Mountain belong to the CHL, both edifices which are characterized by the occurrence of the silica undersaturated rocks unless abundant in the Cameroon Hot line. The Cameroon Hot Line/Cameroon Volcanic Line/Cameroon Line (CL) as well as many other volcanic provinces across the African plate is characterized by associations of Tertiary to recent volcanism [2]. It forms one of the major geologic lineaments of the African plate. It is evident that the contention over its geodynamic origin of the megastructure which across the Cameroon country along the 1600 $\mathrm{km}$ is linked of the complex features on the linear alignment of the volcanoes but lack of a consistent time-space migration. The Cameroon hot line is dominated by magmatic rocks. The variations of magma and chemistry are generally due to the difference of physical conditions and chemistry in the magma source region during the ascent of magma. Magmatic rocks are differentiated by several petrological processes such as 1) different degrees of melting of the source rocks, 2) crystal fractionation in magma chambers (fractional crystallization, FC), 3) contamination of the magma via assimilation of the wall-rocks (assimilation), and 4) mixing of magmas of different compositions [3]. Specially, Etinde Mountain occur a particularity petrography of the nephelinite while it shares the same basement rocks of the Mount Cameroon which, addition to the dominating of the basaltic lavas, present other rare rocks such as camptonite. In this paper, ten samples from three different localities and four different rocks types have been studied (nephelinite or clinopyroxene nephelinite, basalt and camptonite) to compare major and trace elements and discuss the relationship between the silica undersaturated rocks in the both edifice: Mount Cameroon camptonite rocks and Mount Etinde nephelinite which characterize the lateral variation appear through the petrography of the different rocks. 


\section{Geological Setting}

The Cameroon Volcanic Line (CVL), also called the Cameroon Line [4] or Cameroon Hot Line [5], is made up of an alignment of mountains trending N30 and is divided into two parts: an oceanic part with volcanic islands of Gulf of Guinea and a continental part characterized by volcanic eruptions of Mount Cameroon and deadly gas emissions from lakes Monoun in 1984 and Nyos in 1986, respectively (Figure 1). The Cameroon Hot line or Cameroon line consist of two sections: The oceanic section and the continental section. The oceanic section lies within the Gulf of Guinea consisting of the islands of Pagalu, São Tomé, Principe, and Bioko and the continental section is made the several volcanic mountains by an alternation of horsts and grabens [6]. Main mountains are mount (Mt) Cameroon $(4095 \mathrm{~m})$ which is the highest and the most active volcanoes of the CVL, mainly formed by alkaline basalts [5] [7].

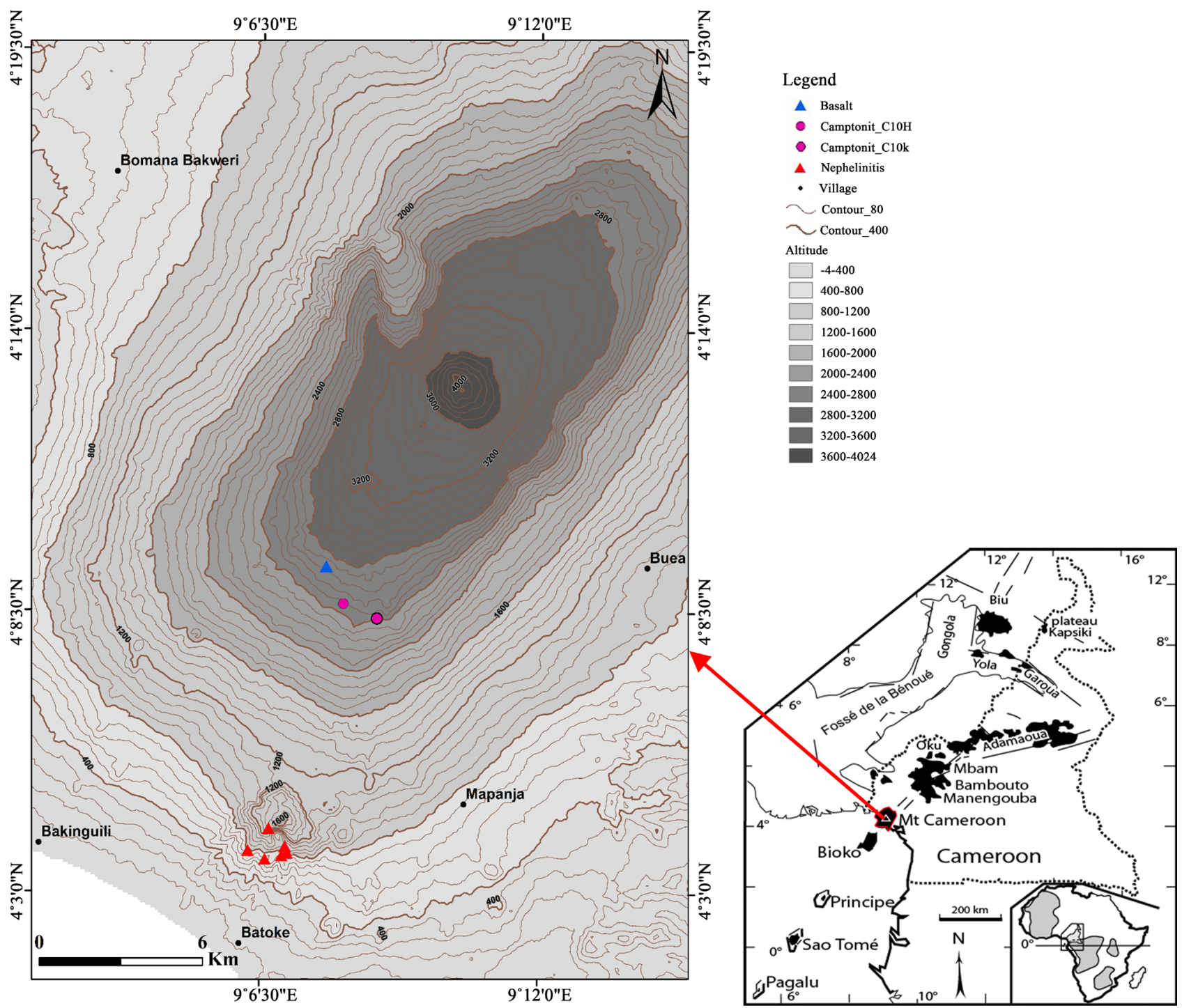

Figure 1. Regional contour map of Mount Cameroon and Mount Etinde: The Mount Cameroon basalt (Bleu triangle), camptonite (reddish circle) and the Mount Etinde nephelinite (red triangle). 
Mount Cameroon is typically a basaltic volcano that forms part of a long line of volcanoes referred to regionally as the Cameroon Hot line [5] against the Mount Etinde which is stratovolcanco cone consisting of layered nephelinitic tuff, nephelinite to hauyne melilite or garnet-red, leucito-nephelinite to hauynophyres [8] [9]. The mount Etinde edifice shows a depression at $4^{\circ} 5^{\prime} \mathrm{E}$ and $9^{\circ} 6^{\prime} \mathrm{N}$ which can be interpreted as the collapse of the volcanic products during the destabilization of the flank and/or the flaring of lavas frightening a bed due to the tension of the flank. Several geological and geophysical studies have been specially carried the mount Cameroon volcano and out along the CVL to understand its structure, origin and evolution in general. Mount Cameroon and Mount Etinde share the same basement rocks with the volcanoes. They are characterized by the eruption of a type but with proximal pahoehoe occurring locally near the vents [10]. According by [11] the presence of the nephelinite rocks and camptonite rocks in the same block of the volcano, both volcanic rocks silica-undersaturated, show clearly a link with the tectonic process in opening zone as well as Atlantic Ocean which belong to extension domain along to the Cameroon Hot line.

\section{Petrography and Mineral Composition}

In addition to samples collected for this study, the investigated nephelinite samples are petrographically fresh, contain secondary minerals and are mostly porphyritic or slightly porphyric. The mineral phases are often characterized by euhedral and subhedral crystal habits. Clinopyroxene phenocrysts and microphenocrysts sometimes show columnar habit. The groudmass comprises clinopyroxene, titano-magnetite, and nepheline. A detail petrographic and mineralogy from Mount Etinde nephelinitic rocks are presented by [8] [9] [12] [13]. Mineral assemblage of the basalt C10J reveals clinopyroxene, amphibole and biotite against Mt Cameroon camptonites which contain phenocrysts of clinopyroxene or olivine, plagioclase, amphibole and biotite and titanomagnetite scattered in a groundmass of the same minerals and also contain nepheline or analcime and carbonate [14]. The mineral assemblages of the nephelinite are similar of the camptonite $(\mathrm{C} 10 \mathrm{H})$ with the small difference in the representative modal mineral. Petrographically and mineralogy of the Mt Etinde nephelinite and Camptonite are quite similar and have porphyritic texture except for the absence of plagioclase in the nephelinite.

\section{Geochemistry}

\section{Analytical procedures}

Analytical data for major and trace elements determined of the Mt Etinde nephelinite and Mt Cameroon camptonite and basalt were done in based on electron microprobe instrument (CAMEBAX SX 50 at the University of Marie Curie, Paris) [9] [11].

\section{Major elements}




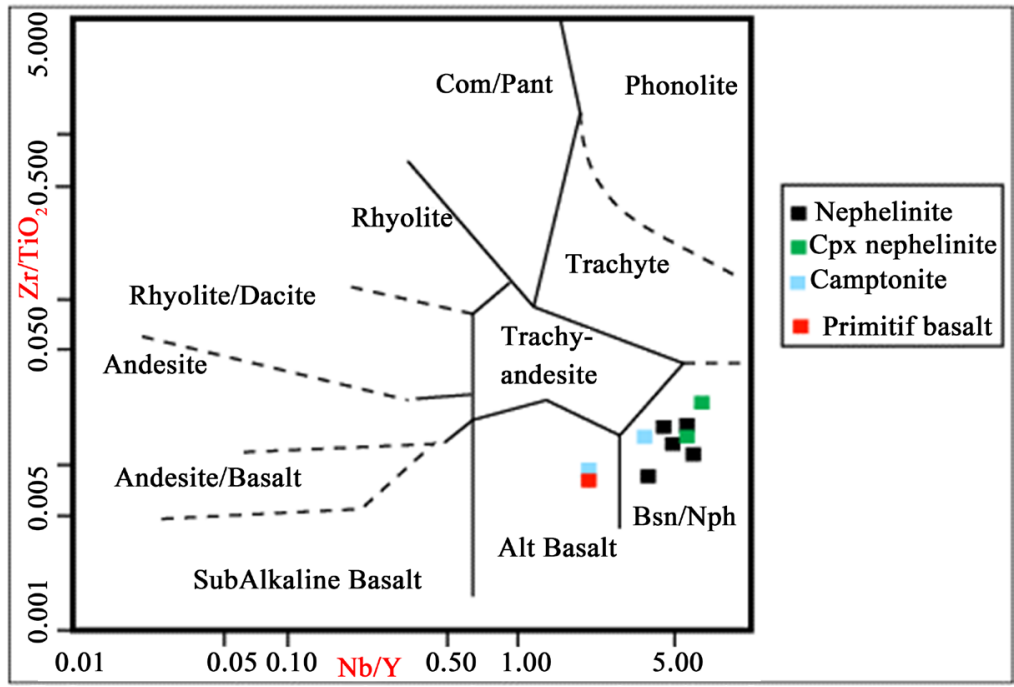

Figure 2. $\mathrm{Nb} / \mathrm{Y}-\mathrm{Zr} / \mathrm{TiO}_{2}$ diagram [15].

The whole-rock compositions of the studied samples are presented in Table 1. A slightly lower content of $\mathrm{MnO}$ is also typical of the Cameroon hot line. The classification of the samples, based on the total alkali-silica diagram Figure 2 [15] show the Mt. Cameroon camptonite, basalt and Mount Etinde nephelinite plot in two major fields. Difference in the fractionation processes resulted in the differences in differentiation index (D.I.) variation. Major elements chemical analyses for the representative rock samples along with their CIPW norms and DI are given in Table 1. The differentiation index ranges from 14.15 to 54.61 and confirm the alkali nature of the studied samples in the two edifices (Mount Cameroon and Mount Etinde). Analysis of behaviour of the major elements in all sample indicated the presence of one group of rock which, differed in silica and alkali contents but with the alkali affinity. Variation in major elements against D.I. is shown on the variation diagrams of Figure 3. The $\mathrm{CaO}$ and $\mathrm{Al}_{2} \mathrm{O}_{3}$ demonstrated opposite trends. Concentration of major oxides such as $\mathrm{MgO}$, $\mathrm{CaO}$, show a negative correlation with increase in D.I. while $\mathrm{TiO}_{2}, \mathrm{Al}_{2} \mathrm{O}_{3}, \mathrm{~K}_{2} \mathrm{O}$ are increased. With increasing D.I. the alkali contents are scattered although $\mathrm{Al}_{2} \mathrm{O}_{3}, \mathrm{P}_{2} \mathrm{O}_{5}$ and $\mathrm{Fe}_{2} \mathrm{O}_{3}$ decreases slightly from the $\mathrm{TiO}_{2}, \mathrm{CaO}$ and $\mathrm{K}_{2} \mathrm{O}$. This is due probably to the early crystallization of the different minerals phases.

The $\mathrm{CaO}$ and $\mathrm{MgO}$ decrease with increasing DI reflects clinopyroxene fractionation affected by crystallisation of carbonate minerals. The characteristic features of this suite are the high $\mathrm{CaO}$ for nephelinite $(11.2 \%-16.2 \%)$ compared of the Mount Cameroon camptonite $(8.4 \%-10.7 \%$ and low alkali contents of the primitive lavas, in sharp contrast to the primitive high-k basalt.C10J.

\section{Trace elements}

The normalized abundance of incompatible elements in representative rocks is demonstrated in Figure 4. This diagram shows abundance patterns of moderaly highly compatible elements normalized concentrations in the primitive mantle [16]. The content of $\mathrm{Zr}$ and $\mathrm{Nb}$ in the analysed nephelinite range from 


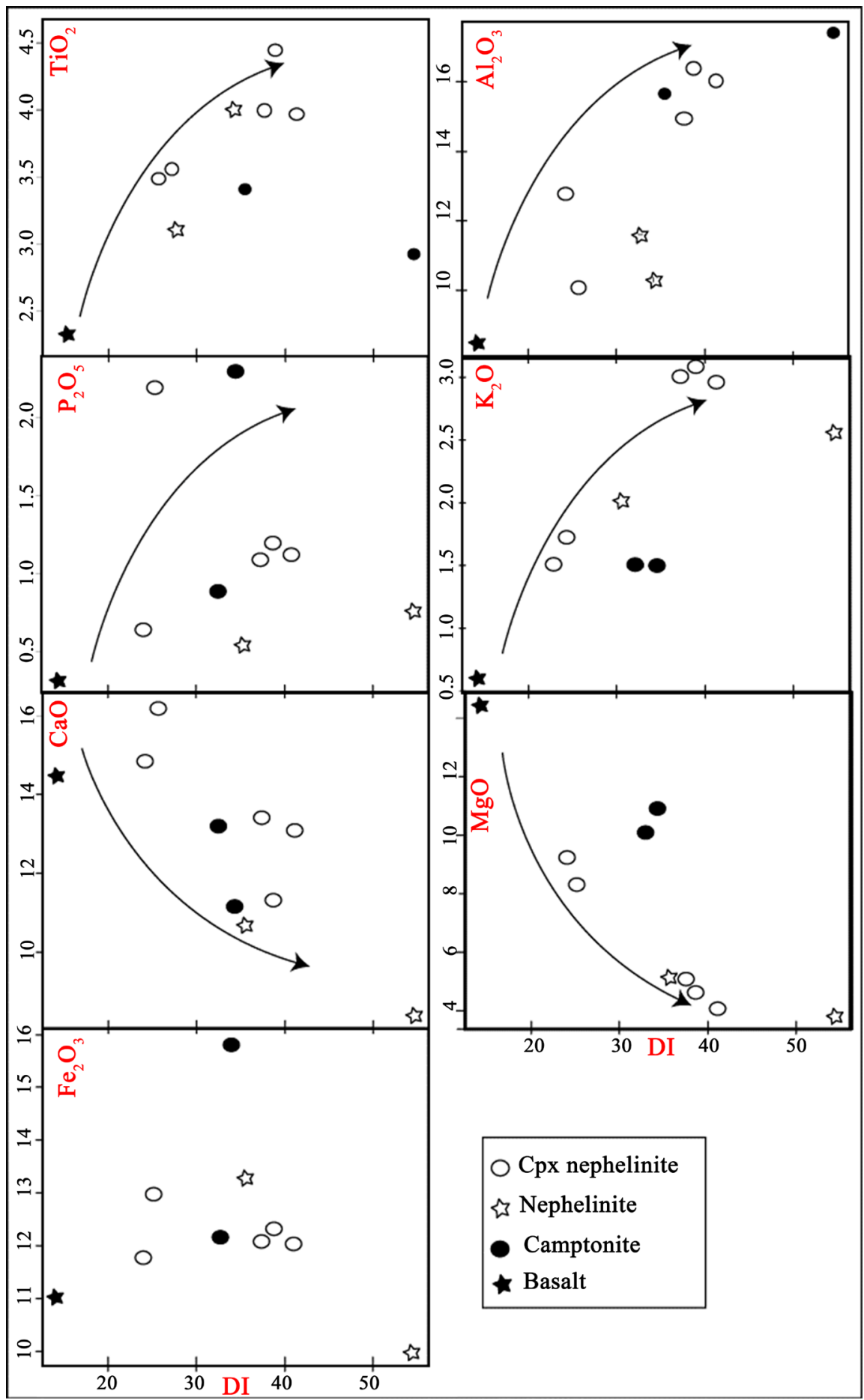

Figure 3. Diagrams major oxides (wt\%) versus D.I. of the Mt. Cameroon and Mount Etinde DI $=\mathrm{CIPW}$ normative $\mathrm{Qz}+\mathrm{Or}+\mathrm{Ab}+\mathrm{Ne}$.

183 to 728 and from 39 to 267 respectively and highest the camptonite and basalt. The compatible elements, $\mathrm{Ni}, \mathrm{Cr}, \mathrm{Co}$, and $\mathrm{Sc}$ are more concentrated in ferromagnesian minerals than in coexisting melt in the silica undersaturated rocks excepted the basalts $\mathrm{C} 10 \mathrm{~J}$ with high $\mathrm{Ni}=275 \mathrm{ppm}$. All rocks show similar distribution patterns, though their elemental contents may differ by some elements 
( $\mathrm{Ba}$ and $\mathrm{Yb}$ ). Several geochemical studies have been carried the mount Cameroon showed that alkali basalts are enriched in $\mathrm{Sr}, \mathrm{Ba}$ and $\mathrm{Rb}$, but depleted in $\mathrm{Ta}$, $\mathrm{K}, \mathrm{P}, \mathrm{Nb}$ and $\mathrm{Ti}$ as compared with the samples collected from the location on the Mount Etinde [14] [17] [18]. All rocks were depleted in K, P and Ti and this character are typical of alkaline rocks.

The studied samples rocks of both edifices present fractionated rare earth element (REE) patterns in chondrite-normalised REE plots. A chondrite normalised REE diagrams of [16] (Figure 5) shows LREE enrichment versus HREE from basalt to nephelinite. Highly fractionated REE compositions of selected

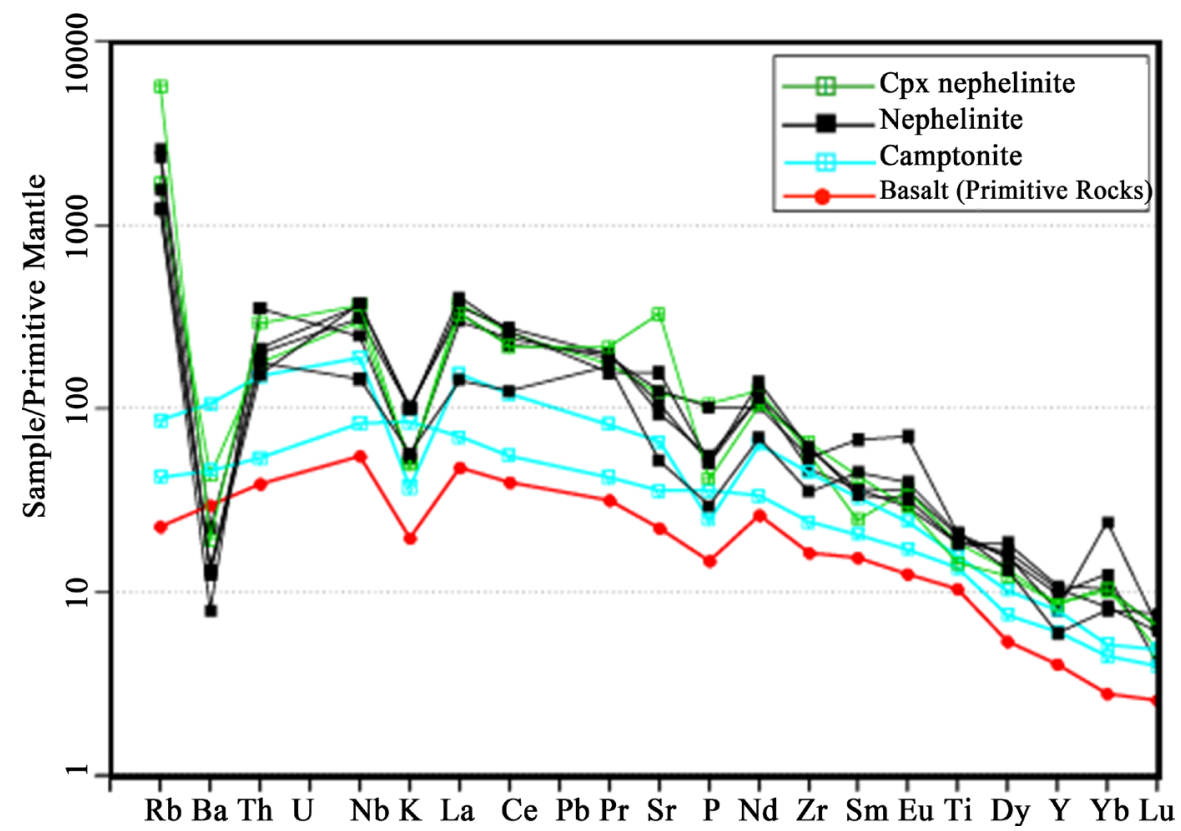

Figure 4. Chondrite-normalized multi-element diagram of the nephelinite and camptonite, data after [16].

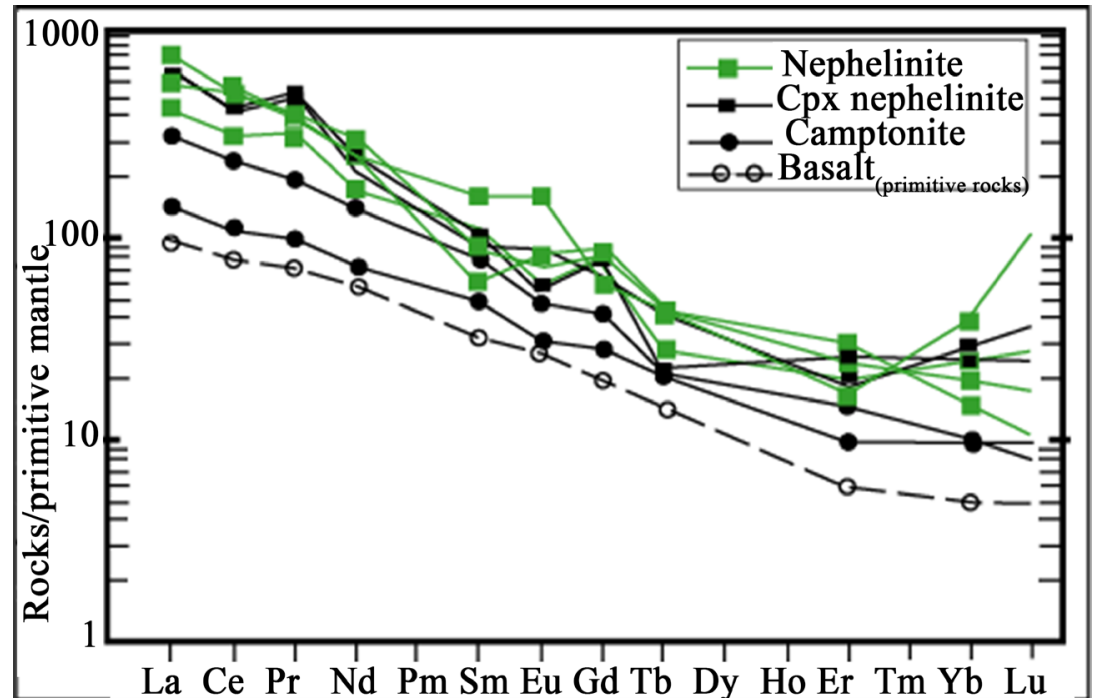

Figure 5. Chondritite normalized REE patterns of the Mount Cameroon camptonite, basalt and Mount Etinde nephelinite. 
representative samples of the all samples are presented in Figure 6. Mount Etinde nephelinite show chondrite-normalized REE patterns similar to that of the Mount Cameroon camptonite. The spectrum of nephelinite and camptonite are superimposed and are parallel with basalt which considering as well as the primitive sample. Chondrite normalised REE patterns present LREE the strong enrichment relative to HREE, similar to other alkali rocks from the Cameroon Hot Line [5] [6] [19] [20]. The rare-earth element compositions of basaltic, camptonite rocks from Mount Cameroon and nephelinite rocks are given for comparaison in Table 1.

Table 1. Representative analysis of all studied samples (Mt Etinde nephelinite, camptonite and basalt from Mt Cameroon).

\begin{tabular}{|c|c|c|c|c|c|c|c|c|c|c|}
\hline (W\%) & ME33 & ME23 & ME44 & ME22 & $\mathrm{ClOK}$ & $\mathrm{C} 10 \mathrm{H}$ & $\mathrm{C} 10 \mathrm{~J}$ & ME111 & ME150 & ME20 \\
\hline $\mathrm{SiO}_{2}$ & 39.01 & 43.4 & 38.89 & 40.21 & 47.19 & 45.86 & 45 & 42 & 39.4 & 39.89 \\
\hline $\mathrm{TiO}_{2}$ & 4.46 & 4.01 & 4.57 & 4 & 2.93 & 3.41 & 2.27 & 3.1 & 4.5 & 3.98 \\
\hline $\mathrm{Al}_{2} \mathrm{O}_{3}$ & 16.34 & 10.3 & 10.1 & 15 & 17.39 & 15.64 & 8.43 & 11.6 & 12.83 & 16.1 \\
\hline $\mathrm{Fe}_{2} \mathrm{O}_{3}$ & 12.34 & 15.8 & 13.02 & 12.1 & 9.97 & 13.31 & 11.07 & 12.2 & 11.78 & 12.01 \\
\hline $\mathrm{MnO}$ & 0.27 & 0.5 & 0.3 & 0.29 & 0.18 & 0.19 & 0.18 & 0.2 & 0.3 & 0.28 \\
\hline $\mathrm{MgO}$ & 4.67 & 10.9 & 8.4 & 5.16 & 3.84 & 5.16 & 14.46 & 10.1 & 9.18 & 4.1 \\
\hline $\mathrm{CaO}$ & 11.35 & 11.2 & 16.2 & 13.43 & 8.41 & 10.72 & 14.47 & 13.2 & 14.81 & 13.1 \\
\hline $\mathrm{Na}_{2} \mathrm{O}$ & 3.72 & 3.00 & 2.72 & 4.44 & 5.78 & 3.42 & 1.26 & 4.5 & 2.86 & 5.07 \\
\hline $\mathrm{K}_{2} \mathrm{O}$ & 3.07 & 1.50 & 1.60 & 3.00 & 2.55 & 1.12 & 0.59 & 1.50 & 1.71 & 2.98 \\
\hline $\mathrm{P}_{2} \mathrm{O}_{5}$ & 1.2 & 2.3 & 2.2 & 1.09 & 0.77 & 0.54 & 0.32 & 0.9 & 0.64 & 1.11 \\
\hline PF & 1.66 & 0.78 & 1.21 & 0.83 & 0.58 & 0.43 & 1.87 & 2.01 & 0.92 & 1.22 \\
\hline Total & 98.09 & 103.69 & 99.21 & 99.55 & 99.59 & 99.8 & 99.92 & 101.31 & 98.93 & 99.84 \\
\hline $\mathrm{Ba}(\mathrm{ppm})$ & 155 & 301 & 55 & 92 & 322 & 736 & 205 & 134 & 91 & 87 \\
\hline $\mathrm{Rb}$ & 1645 & 1063 & 781 & 989 & 26.8 & 54.7 & 14.3 & 3622 & 777 & 1500 \\
\hline Th & 18 & 15 & 30 & 17 & 4.56 & 12.75 & 3.26 & 25 & 15 & 13 \\
\hline $\mathrm{Sr}$ & 1967 & 2543 & 2625 & 2234 & 745 & 1387 & 473 & 6923 & 1100 & 3311 \\
\hline $\mathrm{Zr}$ & 522 & 623 & 605 & 667 & 269 & 504 & 183 & 728 & 392 & 690 \\
\hline $\mathrm{Nb}$ & 263 & 214 & 177 & 222 & 59 & 135 & 39 & 263 & 103 & 267 \\
\hline $\mathrm{Ni}$ & 12 & 11 & 25 & 12 & 43 & 23 & 279 & 13 & 47 & 16 \\
\hline Co & 67 & 44 & 87 & 42.3 & 35 & 21 & 57 & 32 & 14.8 & 63.4 \\
\hline $\mathrm{Zn}$ & 156 & 133 & 97 & 133 & 113 & 100 & 88 & 159 & 104 & 153 \\
\hline $\mathrm{Cr}$ & 2 & 10 & 14 & 10 & 31 & 25 & 1304 & 7 & 13 & 13 \\
\hline $\mathrm{La}$ & 226 & 257 & 205 & 244 & 47.9 & 105.7 & 32.7 & 224 & 98 & 276 \\
\hline $\mathrm{Ce}$ & 392 & 453 & 431 & 488 & 98 & 212 & 70 & 387 & 221 & 465 \\
\hline $\operatorname{Pr}$ & 55.1 & 48.3 & 52.3 & 54.1 & 11.6 & 22.5 & 8.7 & 60.1 & 47.5 & 43.2 \\
\hline $\mathrm{Nd}$ & 155 & 170 & 139 & 188 & 45.1 & 86.3 & 35.1 & 142 & 94 & 156 \\
\hline
\end{tabular}




\section{Continued}

\begin{tabular}{|c|c|c|c|c|c|c|c|c|c|c|}
\hline $\mathrm{Sm}$ & 16 & 11 & 30 & 16 & 9.1 & 14.6 & 6.8 & 19 & 20 & 15 \\
\hline $\mathrm{Eu}$ & 6 & 6 & 11.8 & 4.9 & 2.88 & 4.06 & 2.1 & 4.9 & 6.7 & 5.4 \\
\hline Gd & 17 & 23 & 15.6 & 22.4 & 7.68 & 11.36 & 5.51 & 20 & 18 & 22 \\
\hline $\mathrm{Tb}$ & 2.2 & 1.5 & 2.56 & 1.92 & 1.09 & 1.6 & 0.76 & 1.9 & 2.38 & 2.3 \\
\hline Dy & 11.2 & 9.86 & 11.45 & 13.58 & 5.55 & 7.56 & 3.97 & 8.96 & 9.78 & 12.35 \\
\hline V & 245 & 345 & 287 & 212 & 294 & 215 & 235 & 254 & 299 & 197 \\
\hline $\mathrm{Er}$ & 4.23 & 5.12 & 3.89 & 4.23 & 2.44 & 3.3 & 1.66 & 5.17 & 6.3 & 5.28 \\
\hline $\mathrm{Tm}$ & 0.36 & 0.46 & 0.52 & 0.46 & 0.33 & 0.46 & 0.23 & 0.48 & 0.56 & 0.55 \\
\hline $\mathrm{Yb}$ & 6.1 & 5.2 & 11.8 & 5.1 & 2.18 & 2.55 & 1.37 & 5.01 & 3.9 & 4.1 \\
\hline $\mathrm{Lu}$ & 0.31 & 0.36 & 0.49 & 0.475 & 0.29 & 0.36 & 0.19 & 0.49 & 0.56 & 0.45 \\
\hline $\mathrm{Y}$ & 44 & 39 & 36 & 49 & 27.4 & 36.4 & 18.3 & 39 & 27 & 47 \\
\hline \multicolumn{11}{|c|}{ CIPW norms (calculated with $1.5 \mathrm{~W} \% \mathrm{Fe}_{2} \mathrm{O}_{3}$ ) and differentiation index (D.I.) } \\
\hline Or & 18.14 & 8.87 & 9.46 & 16.94 & 15.07 & 6.62 & 3.49 & 8.87 & 10.11 & 17.61 \\
\hline $\mathrm{Ab}$ & 7.69 & 25.39 & 7.59 & 0.00 & 28.46 & 28.94 & 10.66 & 6.94 & 1.89 & 0.35 \\
\hline An & 18.82 & 10.21 & 10.62 & 12.14 & 13.97 & 24.015 & 15.60 & 7.02 & 17.12 & 12.37 \\
\hline $\mathrm{Ne}$ & 12.89 & 0.000 & 8.36 & 20.35 & 11.08 & 0.000 & 0.000 & 16.87 & 12.08 & 23.06 \\
\hline $\mathrm{Di}$ & 11.81 & 14.26 & 31.63 & 26.91 & 10.29 & 11.29 & 36.50 & 33.14 & 29.33 & 22.03 \\
\hline $\mathrm{Ol}$ & 4.32 & 4.39 & 4.39 & 0.26 & 3.36 & 4.50 & 10.69 & 6.86 & 6.50 & 0.000 \\
\hline Il & 0.58 & 1.070 & 0.642 & 0.620 & 0.39 & 0.47 & 0.39 & 0.43 & 0.64 & 0.60 \\
\hline $\mathrm{Hm}$ & 12.34 & 15.80 & 13.02 & 12.10 & 9.97 & 13.31 & 11.07 & 12.20 & 11.78 & 12.01 \\
\hline Pf & 7.08 & 1.93 & 7.21 & 6.26 & 4.65 & 0.000 & 0.000 & 4.90 & 7.09 & 6.24 \\
\hline Ap & 2.84 & 5.45 & 5.21 & 2.58 & 1.82 & 1.28 & 0.76 & 2.132 & 1.57 & 2.63 \\
\hline DI & 38.72 & 34.25 & 25.41 & 37.30 & 54.61 & 35.56 & 14.15 & 32.68 & 24.08 & 41.01 \\
\hline
\end{tabular}

The samples of Mount Cameroon and Mt Etinde were product of a low degree of partial melting $(-0.28)$ probably of a mantle peridotite enriched in incompatible elements (Figure 6) [21]. The possibility of crustal assimilation has an impact upon isotopic and incompatible trace element compositions in the different crustal levels during the magma staying in magma chambers [22]. The theoretical curves produced after using the Petromodeler software [3] [23] show different values of $\mathrm{r}=0.4$ (the ratio of the rate of assimilation to the rate of $\mathrm{FC}$ ), $\mathrm{F}=$ 0.63. The results obtained from PCF, AFC and IFC modelling using Upper Continental Crust [24] as contaminating rocks put in evidence the assimilation of carbonates during the evolution of the Si-undersaturated rocks of the Cameroon hot line (e. g. nephelinitic rocks and camptonites). The silica undersaturated character of the both edifice of the CHL is linked of the effect of the rock rich in carbonate assimilated during metasomatism process in the mantle source. According by [25] [26] [27] [28], Si-undersaturated contaminated magmas can be a consequence of carbonate rock assimilation. 


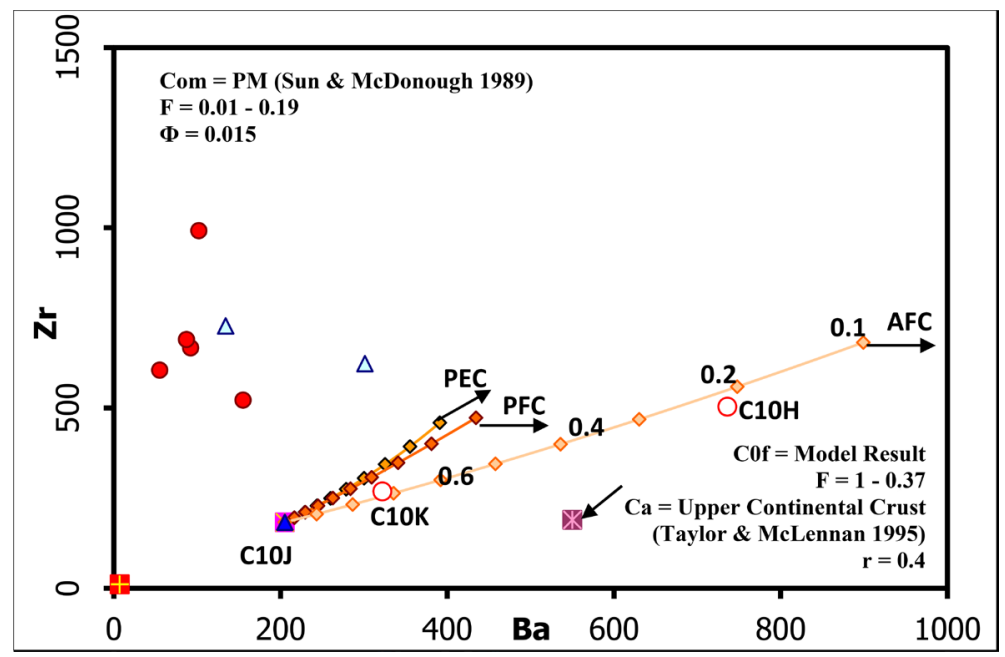

Figure 6. Binary diagram showing the several differentiation trends of $\mathrm{Zr}$ vs. Ba (PFC: Perfect fractional crystallization; AFC: Assimilation with fractional crystallisation, PEC: Perfect equilibrium crystallization) Up.CC: Upper continental crust, r: ratio [21] (Ersoy et al., 2010).

\section{Discussion}

A major process responsible for variation in the composition of nephelinite and camptonite rocks must be fractional crystallization significant. The variation of mafic phenocryst mineral assemblages suggested that the parental magma generated. The lateral variations in compatible elements are consistent with the variation of the content of pyroxene especially diopside between the camptonite and nephelinite highest of clinopyroxene. The samples from Mount Cameroon and mount Etinde were derived from a mantle source contaminated by metasomatic solutions bearing $\mathrm{K}, \mathrm{Ba}, \mathrm{Sr}$, and $\mathrm{Rb}$ and or melts released from the underlying continental plate. The relatively high L.O.I. contents of the nephelinite rocks and primitive basalt are mostly related to alteration to low-temperature phases and the presence of the minor amount of secondary minerals such as zeolites and analcime. [29] [30] suggest that the K negative anomaly is characteristic of the mantle source type of HIMU. The Mount Cameroon camptonites have high incompatible element contents and contain hydrated (kaersuite, biotite) and/or carbonate minerals suggesting that they originate from a volatile-rich intra-lithospheric metasomatized peridotite mantle [11].

According to [9], the investigated nephelinetic rocks are generated from mantle sources that were modified by pneumatholitic components, which were derived from basaltic magma. As seen from Figure 5 the REE patterns of basaltic and camptonite rocks from Mount Cameroon have REE patterns similar to Mt Etinde samples (nephelinetic rocks). These comparable patterns reflect that the studied rocks of Mount Etinde may have been derived from a similar mantle source.

The different data allow for the comparison of the Mount Etinde and Mount Cameroon edifice to reflect the differentiation process, which show their geo- 
chemical affinities relative to probable sources from basaltic magma by the Petromodeler software [3]. The results were compared with data from other lavas along the Cameroon Volcanic Line.

The linear-like trends on Harker diagrams of the studied samples suggest that fractional crystallisation played an important role in their evolution through the different mineral phases. The observed correlations in the Harker diagrams for the Mount Cameroon camptonite and Mount Etinde nephelinite compared of the other rocks of the Cameroon Hot Line probably reflect the significant role of fractional crystallisation processes during their evolution of magmatism in the geodynamic context of Cameroon hot line.

Despite similar REE patterns, camptonite and basalt exhibit less pronounced LREE enrichment than nephelinitic rocks. This enrichment patterns suggests that rocks come from a same source regions, which are enriched in the LREE. The information obtained from the comparison of the spectra nephelinite, camptonite and basalt are almost parallel, implying that they could be related by the fractional of the mineral phases. The REE variation in igneous rocks can be used to evaluate partial melting rates in their sources, where low partial melting generates magmas with a high $\mathrm{Ce} / \mathrm{Yb}$ ratio [31].

\section{Conclusion}

The abundance and distribution of elements in the nephelinite and camptonite samples have been controlled by one or more different geological factors in the Cameroon Hot line. The differences in the compatible elements between the Mount Etinde nephelinite and the Mount Cameroon camptonite and basalt correlate with the difference in modal compositions of mineral phases. The patterns of samples are almost parallel, implying that they could be related by the fractional of a phase that doesn't change the REE. This enrichment patterns suggests that lavas come from source regions, which are enriched in the LREE. The lateral variation of major and trace element contents in the Mount Cameroon camptonite and Mount Etinde nephelinite seem to be related to the difference in the fractional crystallization processes as well as the difference in the partial melting processes and the metasomatism source rich in volatile. Based on geochemical data, the silica-undersaturated character of the camptonite and nephelinite could be attributed to assimilation of carbonate rocks within depth-level magma chambers. Trace element AFC modelling revealed that the parental magmas of both edifice volcanic rocks were mostly affected by fractional crystallisation coupled with metasomatism process in a similar source rich in Ca.

\section{Acknowledgements}

Thanks go to anonymous reviewers for their critical reviews of the manuscript, the members of the scientific team of OJG and the microprobe analyses were performed during the stay of the last author (Ngounouno. I.) based on electron microprobe instrument (CAMEBAX SX 50) at the University of Marie Curie, 
Paris V.

\section{Conflicts of Interest}

The authors declare no conflicts of interest regarding the publication of this paper.

\section{References}

[1] Njome, M.S., Suh, C.E., Sparks, R.J., Ayonghe, S.N. and Fitton, G.J. (2007) The Mount Cameroon 1959 Compound Lava Flow Field: Morphology, Petrography and Geochemistry. Birkhäuser Verlag, Basel. https://doi.org/10.1007/s00015-007-1245-X

[2] Njonfang, E., Nono, A., Kamgang, P., Ngako, V. and Tchoua, F.M. (2011) Cameroon Line Magmatism (Central Africa): A Reappraisal. In: Beccaluva, L., Bianchini, G. and Wilson, M., Ed., Volcanism and Evolution of the African Lithosphere, GSA, London, Special Paper 478, 173-191. https://doi.org/10.1130/2011.2478(09)

[3] Ersoy, Y. and Helvac1, C. (2010) FC-AFC-FCA and Mixing Modeler: A Microsoft ${ }^{\circledR}$ Excel $^{\odot}$ Spreadsheet Program for Modeling Geochemical Differentiations of Magma by Crystal Fractionations, Crustal Assimilation and Mixing. Computers and Geosciences, 36, 383-390. https://doi.org/10.1016/j.cageo.2009.06.007

[4] Ngako, V., Njonfang, E., Tongwa, A.F., Affaton, P. and Metuk, N.J. (2006) The North-South Paleozoic to Quaternary Trend of Alkaline Magmatism from Niger-Nigeria to Cameroon: Complex Interaction between Hotspots and Precambrian Faults. Journal of Africa Earth Science, 45, 241-256. https://doi.org/10.1016/j.jafrearsci.2006.03.003

[5] Déruelle, B., Ngounouno, I. and Demaiffe, D. (2007) The "Cameroon Hot Line" (CHL): A Unique Example of Active Alkaline Intraplate Structure in Both Oceanic and Continental Lithospheres. Comptes Rendus Geoscience, 339, 589-600. https://doi.org/10.1016/j.crte.2007.07.007

[6] Nkouathio, D.G., Kagou, D.A., Bardintzeff, J.M., Wandji, P., Bellon, H. and Pouclet, A. (2008) Evolution of Volcanism in Graben and Horst Structures along the Cenozoic Cameroon Line (Africa): Implications for Tectonic Evolution and Mantle Source Composition. Contributions to Mineralogy and Petrology, 94, 287-303. https://doi.org/10.1007/s00710-008-0018-1

[7] Yokoyama, T., Aka, F.T., Kusakabe, M. and Nakamura, E. (2007) Plume-Lithosphere Interaction beneath Mt Cameroon Volcano, West Africa: Constraints from 238u239Th-226Ra and Sr-Nd-Pb Isotope Systematics. Geochimica et Cosmochica Acta, 71, 1835-1854. https://doi.org/10.1016/j.gca.2007.01.010

[8] Nkoumbou, C., Déruelle, B. and Velde, D. (1995) Petrology of Mt Etinde Nephelinite Series. Journal of Petrology, 36, 376-395. https://doi.org/10.1093/petrology/36.2.373

[9] Ntoumbé, M., Déruelle, B., Gbambie, I. and Ngounouno, I. (2016) New Petrology and Geochemical Data of the Nephelinitic Lavas and Geodynamic Implications of Mount Etinde (Cameroon). International Journal of Geosciences, 7, 1452-1470. https://doi.org/10.4236/ijg.2016.712101

[10] Suh, C.E., Luhr, J.F. and Njome, M.S. (2007) Olivine-Hosted Glass Inclusions in Scoriae Erupted in 1954-2000 at Mount Cameroon Volcano, West Africa. Journal of Volcanology and Geothermal Research, 169, 1-33. https://doi.org/10.1016/j.jvolgeores.2007.07.004

[11] Ngounouno, I., Déruelle, B., Montigny, R. and Demaiffe, D. (2006) Les camptonites 
du Mont Cameroun, Cameroun, Afrique. Comptes Rendus Geoscience, 338, 537-544. https://doi.org/10.1016/j.crte.2006.03.015

[12] Etame, J., Gerad, M., Suh, C.E. and Bilong, P. (2009) Halloysite Neoformation during the Zeathering of Nephelinitic Rocks under Humid Tropical Condition at Mt Etinde, Cameroon. Geoderma, 154, 59-68. https://doi.org/10.1016/j.geoderma.2009.09.013

[13] Etame, J., Suh, C.E., Gerad, M. and Bilong, P. (2012) Phillipsite Formation in Nephelinitic Rocks in Response to Hydrothermal Alteration at Mount Etinde, Cameroon. Chimie der Erde Geochemistry, 72, 31-37. https://doi.org/10.1016/j.chemer.2011.08.002

[14] Ngounouno, I., Déruelle, B., Demaiffe, D. and Montigny, R. (2003) Les monchiquites de Tchircotché, Vallée de la haute Bénoué (Nord du Cameroun). Comptes Rendus Geoscience, 335, 289-296.

[15] Winchester, J.A. and Floyd, P.A. (1977) Geochemical Discrimination of Different Magma Series and Their Differentiation Products Using Immobile Elements. Chemical Geology, 20, 325-343. https://doi.org/10.1016/0009-2541(77)90057-2

[16] Sun, S. and McDonough, W.F. (1989) Chemical and Isotopic Systematics of Oceanics Basalts: Implications for Mantle Composition and Processes. Geological Society, London, Special Publications, 42, 313-345.

https://doi.org/10.1144/GSL.SP.1989.042.01.19

[17] Yamgouot, F.N., Déruelle, B., Mbowou, G.I.B. and Ngounouno, I. (2015) Petrology of the Volcanic Rocks from Bioko Island ("Cameroon Hot Line"). International Journal of Geosciences, 6, 247-255. https://doi.org/10.4236/ijg.2015.63019

[18] Chenyi, M.V., Nkouathio, D.G., Wotchoko, P., Djibril, G., Nono, K., Zénon, I., Guedjeo, C.S. and Seuwui, D.T. (2017) Volcanology and Geochemical Study of the Volcanic Rocks of the Bafmeng Area (Mount Oku, Cameroon Volcanic Line). International Journal of Biology Chemistry Sciences, 11, 841-864. https://doi.org/10.4314/ijbcs.v11i2.25

[19] Ngounouno, I., Déruelle, B., Demaiffe, D. and Montigny, R. (2003) Petrology of the Cenozoic Volcanism in the Upper Benue Valley, Northern Cameroon (Central Africa). Contributions to Mineralogy and Petrology, 145, 87-106. https://doi.org/10.1007/s00410-002-0438-6

[20] Moundi, A., Wandji, P., Bardintzeff, J.M., Ménard, J.J., Okomo, A.L.C., Mouncherou, O.F., Reusser, E., Bellon, H. and Tchoua, F.M. (2007) Les basaltes éocènes à affinité transitionnelle du plateau Bamoun, témoins d'un réservoir mantellique enrichi sous la Ligne Volcanique du Cameroun. Comptes Rendus Geoscience, 339, 396-406. https://doi.org/10.1016/j.crte.2007.04.001

[21] Ersoy, E.Y. (2013) PETROMODELER (Petrological Modeler): A Microsoft (R) Excel (R) Spreadsheet Program for Modelling Melting, Mixing, Crystallization and Assimilation Processes in Magmatic Systems. Turkish Journal of Earth Sciences, 22, 115-125.

[22] Cem, Y., Mehmet, A., Irfan, T., Emel, A. and Gilles, R. (2016) Evolution of K-Rich Magmas Derived from a Net Veined Lithospheric Mantle in an Ongoing Extensional Setting: Geochronology and Geochemistry of Eocene and Miocene Volcanic Rocks from Eastern Pontides (Turkey). Gondwana Research, 45, 65-86. https://doi.org/10.1016/j.gr.2016.12.016

[23] Powell, R. (1984) Inversion of the Assimilation and Fractional Crystallization (AFC) Equations; Characterization of Contaminants from Isotope and Trace Element Relationships in Volcanic Suites. Journal of the Geological Society, 141, 447-452. 
[24] Taylor, S.R. and Mclennan, S.M. (1985) The Continental Crust: Its Composition and Evolution. Blackwell Scientific Publication, Oxford.

[25] Peccerillo, A., Federico, M., Barbieri, M., Brilli, M. and Wu, T.W. (2010) Interaction between Ultrapotassic Magmas and Carbonate Rocks: Evidence from Geochemical and Isotopic (Sr, Nd, O) Compositions of Granular Lithic Clasts from the Alban Hills Volcano, Central Italy. Geochimica et Cosmochimica Acta, 74, 2999-3022. https://doi.org/10.1016/j.gca.2010.02.021

[26] Gozzi, F., Gaeta, M., Freda, C., Mollo, S., Di Rocco, T., Marra, F., Dallai, L. and Pack, A. (2014) Primary Magmatic Calcite Reveals Origin from Crustal Carbonate. Lithos, 190-191, 191-203. https://doi.org/10.1016/j.lithos.2013.12.008

[27] Prelević, D., Akal, C., Romer, R.L., Mertz-Kraus, R. and Helvac1, C. (2015) Magmatic Response to Slab Tearing: Constraints from the Afyon Alkaline Volcanic Complex, Western Turkey. Journal of Petrology, 56, 527-562.

https://doi.org/10.1093/petrology/egv008

[28] Lustrino, M., Prelević, D., Agostini, S., Gaeta, M., Di Rocco, T., Stagno, V. and Capizzi L.S. (2016) Carich Carbonates Associated with Ultrabasic-Ultramafic Melts: Carbonatite or Limestone Xenoliths? A Case Study from the Late Miocene Morron de Villamayor Volcano (Calatrava Volcanic Field, Central Spain). Geochimica et Cosmochimica Acta, 185, 477-497. https://doi.org/10.1016/j.gca.2016.02.026

[29] Chauvel, C., Hofmann, A.W. and Vidal, P. (1992) HIMU-EM: The French Polynesian Connection. Earth and Planetary Science Letters, 110, 99-119. https://doi.org/10.1016/0012-821X(92)90042-T

[30] Woodhead, J.D. (1996) Extreme HIMU in an Oceanic Setting: The Geochemistry of Mangaia Island (Polynesia), and Temporal Evolution of the Cook-Austral Hotspot. Journal of Volcanology and Geothermal Research, 72, 1-19. https://doi.org/10.1016/0377-0273(96)00002-9

[31] Rollinson, H.R. (2014) Using Geochemical Data: Evaluation, Presentation, Interpretation. Routledge, London, 384 p. https://doi.org/10.4324/9781315845548 